\title{
Review
}

\section{Acid-Sensing Ion Channels in Glial Cells}

\author{
Victoria Cegielski ${ }^{1}$, Rohan Chakrabarty ${ }^{1}$, Shinghua Ding ${ }^{2,3}{ }^{\oplus}$, Michael J. Wacker ${ }^{1}$, Paula Monaghan-Nichols ${ }^{1}$ \\ and Xiang-Ping $\mathrm{Chu}^{1, *}$ (i)
}

1 Department of Biomedical Sciences, School of Medicine, University of Missouri-Kansas City, Kansas City, MO 64108, USA; vicbmy@umkc.edu (V.C.); rohan.chakrabarty@umkc.edu (R.C.); wackerm@umkc.edu (M.J.W.); nicholsap@umkc.edu (P.M.-N.)

2 Department of Biomedical, Biological and Chemical Engineering, University of Missouri-Columbia, Columbia, MO 65211, USA; dings@missouri.edu

3 Dalton Cardiovascular Research Center, University of Missouri-Columbia, Columbia, MO 65211, USA

* Correspondence: chux@umkc.edu; Tel.: +1-816-235-2248; Fax: +1-816-235-6517

Citation: Cegielski, V.; Chakrabarty, R.; Ding, S.; Wacker, M.J.; Monaghan-Nichols, P.; Chu, X.-P. Acid-Sensing Ion Channels in Glial Cells. Membranes 2022, 12, 119. https://doi.org/10.3390/

membranes12020119

Academic Editors: Tanima Bose and Shiro Suetsugu

Received: 9 December 2021

Accepted: 17 January 2022

Published: 20 January 2022

Publisher's Note: MDPI stays neutral with regard to jurisdictional claims in published maps and institutional affiliations.

Copyright: (C) 2022 by the authors. Licensee MDPI, Basel, Switzerland. This article is an open access article distributed under the terms and conditions of the Creative Commons Attribution (CC BY) license (https:// creativecommons.org/licenses/by/ $4.0 /)$.

\begin{abstract}
Acid-sensing ion channels (ASICs) are proton-gated cation channels and key mediators of responses to neuronal injury. ASICs exhibit unique patterns of distribution in the brain, with high expression in neurons and low expression in glial cells. While there has been a lot of focus on ASIC in neurons, less is known about the roles of ASICs in glial cells. ASIC1a is expressed in astrocytes and might contribute to synaptic transmission and long-term potentiation. In oligodendrocytes, constitutive activation of ASIC1a participates in demyelinating diseases. ASIC1a, ASIC2a, and ASIC3, found in microglial cells, could mediate the inflammatory response. Under pathological conditions, ASIC dysregulation in glial cells can contribute to disease states. For example, activation of astrocytic ASIC1a may worsen neurodegeneration and glioma staging, activation of microglial ASIC1a and ASIC2a may perpetuate ischemia and inflammation, while oligodendrocytic ASIC1a might be involved in multiple sclerosis. This review concentrates on the unique ASIC components in each of the glial cells and integrates these glial-specific ASICs with their physiological and pathological conditions. Such knowledge provides promising evidence for targeting of ASICs in individual glial cells as a therapeutic strategy for a diverse range of conditions.
\end{abstract}

Keywords: acid-sensing ion channels; glial cells; astrocyte; microglia; oligodendrocyte; expression; function

\section{Introduction}

Acid-sensing ion channels (ASICs) are proton-gated cation channels found extensively in the nervous system [1,2]. At least four genes (ACCN 1 to 4 ) have been cloned so far and are categorized as ASIC1-4, with two splice variants identified in ASIC1 and ASIC2 [3,4]. ASICs have more than five-hundred amino acids and consist of two hydrophobic cysteinerich extracellular loops with intracellular $\mathrm{N}$ and $\mathrm{C}$ terminals $[5,6]$. The crystal structure of ASIC1a reveals three subunits forming functional ion channels with multitrimers, heteromers, and homomers [7-9]. Protons or non-proton ligands activate ASICs rendering them permeable to $\mathrm{Na}^{+}$ions mostly, thus the ASICs belong to the degenerin/epithelial sodium channel $(\mathrm{DEG} / \mathrm{ENaC})$ family $[10,11]$. Homomeric ASIC1a is unique in that it is also calcium permeable $[12,13]$. ASICs also exhibit unique half activation $\mathrm{pH}$ values $\left(\mathrm{pH}_{50}\right)$, with functional homomeric ASIC1a, 1b, 2a, and 3 activated at pHs of 6.5, 5.9, 4.4, and 6.6, respectively [14].

Prior reviews have not gathered ASIC information for each of the glial cell types nor discussed how the glial ASICs relate to specific physiology and pathology. Furthermore, most reviews concentrate on ASICs in neurons, while very few have covered their role in glial cells. ASICs are widely expressed in neurons and are less expressed in glial cells throughout the nervous system $[15,16]$. ASIC1a and ASIC2 are highly expressed in both the central and 
peripheral nervous system $[17,18]$. On the other hand, ASIC1b and ASIC3 are primarily expressed in the peripheral sensory neuron [19-21]. Protons are ligands for ASICs and have been shown to act as neurotransmitters in the brain [11,22]. Other non-proton ligands have also been shown to activate these channels at a physiological $\mathrm{pH}$ (e.g., pH 7.4) including the exogenous agent, 2-guanidine-4-methylquinazoline (GMQ), which has been found to activate ASIC3 [23,24], and the coral snake toxin, MitTx, which activates ASIC1 [25].

In light of the pivotal role that ASICs play in several physiological and pathological processes [26,27], select pharmacological blockers of ASICs have been identified and widely used for both research and clinical purposes [28-30]. Amiloride, an $\mathrm{ENaC}$ blocker, is a non-selective and widely used inhibitor of ASICs [1], whereas A-317567 [31] and $\alpha$ dendrotoxin [32] have been reported to block the ASIC currents in dorsal root ganglion neurons. The spider toxin, psalmotoxin-1 (PcTx1), is a selective ASIC1a inhibitor [33,34] that has profound neuroprotective effects against brain ischemia [13], whereas the sea anemone agent, APETx2, is a selective ASIC3 inhibitor that has been shown to modulate pain $[35,36]$. Mambagin, a toxin isolated from black mamba snakes, has been shown to strongly inhibit ASIC1 channels [37,38]. The availability of these select inhibitors has facilitated the dissection of their role in distinct cellular processes [39].

\subsection{Importance of Glial Cells in Neuronal Function}

There are three types of glial cells in the central nervous system (CNS): astrocytes, microglia, and oligodendrocytes [40]. Each of these cell types has a specific role which helps the brain maintain normal physiological function [41-50]. Astrocytes regulate synaptic transmission [51-53], microglia are the primary executors of phagocytosis [54,55], and oligodendrocytes enhance synaptic efficiency by forming myelin sheaths [56,57]. It is worthwhile mentioning that while we discuss the functions of glial cells under conditions of their ablation, glial cell function is highly complex and there exists varied, plastic phenotypes [41-58].

Astrocytes critically regulate neurotransmission and neuronal function throughout the CNS $[42,43,58]$. These cells express high quantities of transporters that are necessary for reuptake of the excitatory amino acid, glutamate [52]. Glutamate excitation is important in regulation of neuronal transmission and coordination of normal motor activity [59]. When astrocytes are nonfunctional and glutamate persists unopposed, inappropriate synaptic regulation and transmission can lead to axonal degeneration and subsequent limb paralysis. Along the same lines, astrocytic ablation results in higher levels of dangerous reactive oxidative species (ROS), indicating that astrocytes play an important role in maintaining redox homeostasis for survival [60]. Astrocytes are also important in regulation of extracellular $\mathrm{K}^{+}$and alterations of blood flow [61,62].

Microglia are essential in maintaining proper brain function through environment surveillance and clearance [44-47]. Although microglia repopulate much quicker than astrocytes $[63,64]$, loss of the microglial cell line causes transient effects on spatial memory [65] and learning behavior [66]. Microglia perform the critical roles of monitoring and phagocytosis in the brain, allowing for proper immune response and effective debris clearance [67]. Constant monitoring and removal of problem materials by these cells promotes a healthy CNS that functions successfully.

Oligodendrocytes play an important role in promoting effective myelin performance [48-50]. More importantly, oligodendrocytes and axons have a complex reciprocal relationship, and oligodendrocytes not only myelinate axons but subsequently shape axonal structure and integrity by providing trophic factors and metabolic support for neurons [49]. Most studies of oligodendrocyte ablation report demyelination as the primary consequence, as well as decreased maintenance and shaping of axonal structure and integrity [68-71]. Secondary findings vary with reports of subsequent remyelination and motor impairment [68], gait disturbances and tremors [68,69], and neuropathic pain [70]. Therefore, oligodendrocytes are necessary for myelin formation and function, ultimately promoting efficient $\mathrm{CNS}$ performance. 


\subsection{Glial Cell Function in Pathological Conditions}

Under abnormal conditions, glial cells exhibit different behaviors which contribute to the appearance of pathology [53-55]. Among astrocytes in the glial fibrillary acidic protein (GFAP)-herpes simplex virus-thymidine kinase (HSV-TK) mouse line, 95\% astrocytic deletion in a spinal cord with stab wound injuries resulted in increased tissue necrosis and higher levels of inflammation [72]. Similar destructive tissue findings were reported in studies that induced astrocytic disruption after experimental autoimmune encephalitis (EAE) to mimic chronic adaptive immune inflammation [73] and traumatic brain injury to the cortex to simulate an acute local inflammatory event [74]. These studies suggest that astrocytes are principal mediators for maintaining brain homeostasis in pathological circumstances. Astrocytes also ensure the efficiency of repair mechanisms on injured areas and prevent the inflammatory response from spreading to locations outside the injury itself [74].

In microglial cells exposed to pathological conditions, contrary effects are observed. In an experiment with over $90 \%$ CD11b-HSV-TK microglia ablation during EAE conditions, inflammatory effects were repressed [75]. This indicates that under inflammatory pathological conditions, microglia perpetuate disease-state conditions by increasing inflammatory effects. On the other hand, in the same mouse line of CD11b-HSV-TK, 75\% microglial ablation in mouse middle cerebral artery occlusion (MCAO) model resulted in a larger area of infarct and more pronounced neuronal death [76]. Under these ischemic conditions, microglia diminish the extent of injury and reveal a protective function against brain ischemia. Therefore, microglia demonstrate different effects in different pathological states; in inflammatory conditions, microglia tend to perpetuate damage, whereas in acute ischemic conditions, microglia alleviate the extent of injury.

Deletion of oligodendrocytes under specific pathological conditions has not been experimentally performed yet. As discussed earlier, however, many studies have ablated oligodendrocytes under healthy physiological conditions. All these studies report similar results of demyelination and disintegrated axonal support [68-71], with varying secondary effects.

ASICs are expressed in glial cells [67], indicating that they could play certain roles in physiological and pathological conditions. In this review, we concentrate on the unique ASIC components in each of the glial cells and integrate these glial-specific ASICs with their physiological and pathological conditions. Understanding the prevalence and function of ASICs is an important step toward potential breakthrough therapies, and targeting of ASICs in individual glial cells could serve as an ideal therapeutic to delay neurodegeneration, decrease ischemic brain injury, and prevent progression of glial brain tumors.

\section{ASICs in Astrocytes}

ASIC1, ASIC2, and ASIC3 have been detected in the astrocytes [77]. ASIC1 contributes to rapid depolarization of astrocytes, whereas ASIC2 and ASIC3 generate sustained currents and thus are slowly depolarizing [77]. Of these, ASIC1a is the most prevalent ASIC in human astrocytes [78]. ASIC1a colocalizes with other ion channel subunits, including $\alpha$ and $\gamma \mathrm{ENaC}$, to form a channel on the plasma membrane of astrocytes and induce depolarization upon stimulation [79]. ASIC1a physiologically functions by allowing the influx of $\mathrm{Na}^{+}$and $\mathrm{Ca}^{2+}$ ions when $\mathrm{pH}$ levels drop below 7.0 [78]. In astrocytes, such depolarization and signaling might be fundamental to the aforementioned functions of motor coordination [52,59,80], ROS mediation [60,81], and blood flow regulation [61,82]. However, the exact role of ASIC1a in astrocytes is not certain, and future studies would need to directly focus on this using astrocyte-specific genetic methods in order to determine its significance in physiology and pathology. Furthermore, the specific role of ASIC2 and ASIC3 in astrocytes is yet to be elucidated.

One feature that distinguishes functional ASIC1a from other ASIC components is its unique permeability to $\mathrm{Ca}^{2+}$, in addition to $\mathrm{Na}^{+}[12,13]$. Calcium influx occurs during activation of astrocytic ASIC1a, as well as trafficking ASIC1a to the cell membrane under acidic extracellular conditions [78]. Intracellular $\mathrm{Ca}^{2+}$ plays an important role in long-term 
potentiation (LTP), which is critical for synaptic plasticity that contributes to learning and memory by activation of ASIC1a in neurons [83-85]. Astrocytic ASIC1a might contribute to synaptic plasticity such as LTP and long-term depression (LTD). This can definitively be confirmed in future studies since ASIC1a knockout (KO) mice are available [83].

ASICs are involved in neurodegenerative diseases $[26,86,87]$. The following experiments highlight the role of ASICs in exacerbating disease states. Using EAE as the experimental mouse model of multiple sclerosis (MS), the role of ASIC1 in this pathological state was examined [88]. It was found that ASIC1 KO mice had less axonal degeneration than their wild-type (WT) mice counterparts, indicating that ASIC1 progresses the degenerative process of MS [88]. This was very similar to findings in mice induced by 1-methyl-4phenyl-1,2,3,6-tetrahydropyridine, a chemical model of Parkinson's disease (PD) [89]. PD is characterized by loss of dopaminergic neurons in the substantia nigra, where ASIC1a components are also located [89]. When ASIC1a was inhibited by its very effect inhibitor PcTx1, neurons were protected from degeneration [89]. In transgenic mice with the mutated ataxin-1 gene, a phenotype corresponding to spinocerebellar type 1 ataxia was observed, ASIC1 KO mice presented with improved motor function under this phenotype [90]. ASIC1 $\mathrm{KO}$ mice also upregulate the ubiquitin-proteasome system, which has been implicated in decreased huntingtin-polyglutamine accumulation [91]. The improved function of mice with deletion of ASIC1 or inhibition of ASICs support the idea of protective effects under ASIC1 inhibition or disruption. While there is more literature focusing on ASIC1 in neurons, it is important to note that ASIC1 has also been discovered in astrocytes. This puts forth the question of the exact role that astrocytic ASIC1 may play in conditions such as neurodegeneration. It is possible that ASIC1 in astrocytes is the primary channel disrupting homeostasis in these pathological conditions, but ASIC1 in neurons, oligodendrocytes, and microglia could also shape axonal structure and integrity. Therefore, astrocyte-specific deletion using conditional $\mathrm{KO}$ mice by crossing astrocyte-specific Cre driver mice such as GLAST-CreERT2, GFAP-CreERT2, and ALDH1L1-CreERT2 lines with floxed ASIC1 mice would be necessary in order to distinguish the specific function of ASIC1 in astrocytes.

In a mouse $\mathrm{MCAO}$ model, ASIC1a demonstrated a role in ischemic brain injury due to its calcium-dependent or calcium-independent mechanisms [13,92]. Activation of ASIC1a by acidosis, as a consequence of ischemic brain injury, leads to elevated intracellular calcium which contributes to pathological distress [13]. Additionally, the acidic environment created by strokes also causes ASIC1a to couple with an enzyme, receptor-interacting serine/threonine-protein kinase 1, triggering neuronal death through necroptosis [93,94]. Increased protease activity as a result of stroke has been implicated in increased ASIC1a activation which further contributes to ischemic brain injury [95]. Given these findings, it follows that when ASIC1a is inhibited under ischemic conditions, neuroprotection is observed $[13,96]$. Future studies can concentrate on ASIC1a in astrocytes to localize specific cellular changes contributing to brain ischemia.

Finally, a role for ASICs in brain tumors has been established. ASIC1a is highly expressed in malignant gliomas $[97,98]$ and selective inhibition of ASIC1a by PcTx1 leads to a decrease in the rate of glioma cell growth [99] and significant inhibition of glioma cell migration [79,100]. Interestingly, ASIC2 in astrocytes inhibits the growth of gliomas [101]. When ASIC2 is not expressed, specific negative effectors requiring this channel are nonfunctional. This causes ASIC1 action to be unopposed, and leads to a basally-active cation current which characterizes glioma cells [101]. The results of these ASIC experiments demonstrate the integral role that ASIC1a has in accelerating glioma. In addition to neoplastic growth, ASIC1a activation is also a likely contributing factor to the high rates of epileptic seizures seen in glioma patients. This seizure-prone behavior is a consequence of extracellular acidosis which, in the absence of any neuronal signaling, induces ASIC1a depolarization in glioma cells and triggers electrical activity in brain circuits [102]. Furthermore, ASIC1a in gliomas induces electrical currents that promote cell proliferation, perpetuating the tumor prognosis [102]. This is confirmed by the fact that glioma proliferation and migration is inhibited by the ASIC1a inhibitor toxin, PcTx1 [79,97,98], as well as ASIC2 [101]. Therefore, 
ASIC1a in gliomas has widespread effects, through both malignancy of the cancer itself, as well as neurological side effects. Research focused on ASIC1a in astrocytes of gliomas may provide a direction in determining cellular targets to prevent cancer progression.

\section{ASICs in Microglial Cells}

ASIC1a, 2a and 3 are expressed in microglial cells [103]. Another ion channel, voltagegated proton channel $\left(\mathrm{H}_{\mathrm{V}}\right)$ subtype 1 , is prominently expressed in microglial cells and plays a role in free radical generation that contributes to ischemic brain injury [104]. Recent studies have confirmed that $\mathrm{H}_{\mathrm{V}} 1$ is also involved in electrical signaling by activating ASIC1a in microglial cells, leading to further proton influx of $\mathrm{Na}^{+}$and $\mathrm{Ca}^{2+}$ [105].

ASIC1a and ASIC2a contribute to the physiological function of microglial cells $[87,103]$. As was noted in the astrocyte section, ASIC1 is sensitive to small drops in pH; its threshold is around $7.0[14,106]$. ASIC2a, on the other hand, is not as sensitive to drops in $\mathrm{pH}$ and is only activated under much more acidic conditions, with a $\mathrm{pH}$ threshold of 5.5 for activation of ASIC2a homomers [14]. One of the physiological roles of ASIC2a is to increase ASIC1 co-localization to dendritic spines, facilitating normal neuronal function $[107,108]$. Without ASIC2a expression, there is less ASIC1 trafficking to cell membranes $[107,108]$. ASIC3 is primarily involved with pain modulation [15,21,109-111]. It has a $\mathrm{pH}$ threshold close to that of ASIC1 [4,112,113], and can be activated for experimental purposes by the non-proton ligand GMQ $[23,24]$. When ASIC3 is highly expressed in microglial cells due to low $\mathrm{pH}$ conditions, hyperalgesia to various insults is observed [114]. Furthermore, when ASIC3 is genetically deleted or inhibited by the peptide toxin, APETx2, fatigue-induced hyperalgesia is diminished [114].

The primary function of microglia is their role in environment surveillance and phagocytosis [63,115]. As microglia age, their execution in debris removal decreases; this dysfunction plays a major role in plaque formation. $\mathrm{A}_{\beta}$ plaque accumulation is characteristic of Alzheimer's disease (AD) [116]. In addition to decreased efficacy in phagocytosis, aged microglia produce storms of inflammatory cytokines and ROS that create a positive feedback loop contributing to continued plaque formation and microglial dysfunction [116]. In particular, ASIC1 and ASIC2a are the most prevalent inflammatory respondents in microglia. This was demonstrated by the upregulation of ASIC1 and ASIC2a when stimulated by LPS, an inflammatory inducer [61,103]. Under LPS stimulation, when the nonspecific ASIC inhibitor, amiloride, or the selective ASIC1a inhibitor, PCTx1, were added, depolarization was prevented and there was reduced expression of inflammatory cytokines that activate enzymes such as nitric oxide (NO) synthase and cyclooxygenase 2 [103]. Such findings demonstrate how ASIC1 and ASIC2a in microglial cells contribute to cytokine storms. Consequently, when inflammation is overstimulated and causes overaccumulation of inflammatory cytokines and cellular debris, cellular senescence and neurodegeneration pursue [117].

Our recent study focusing on ASIC2 pathogenesis in ischemic brain injury found that in hippocampal, cortical, and striatal neurons, deletion of ASIC2 reduced surface ASIC1a levels, acid-activated current density, and acidosis/ischemia-induced neuronal injury [108]. We also found that, in cerebellar neurons with much less ASIC2 expression, ASIC2 deletion had no effect on surface ASIC1a level, acid-activated current density, or acidosis/ischemia-induced neuronal injury, suggesting that heteromeric ASIC1a/2 channels in certain brain regions are likely to contribute to ischemic brain injury [108]. With the established connection between ASIC1a and ischemic brain injury, these findings open the door for future research surrounding neuromodulation of ASIC2 to help mitigate neuronal injury after stroke. This could play an important role in targeted therapy due to the fact that there is a region-specific difference in the pathophysiology of ASIC2. Due to ASIC2 KO mice used in these studies, one possibility is that microglial ASIC2 is involved in this process. However, future studies need to explore whether microglial ASIC2 is directly involved in the ischemic brain injury.

Expression of ASIC3 in response to stimuli induces primary and secondary hyperalgesia [87]. Thus, pain associated with primary inflammation or inflammation induced by 
microglial dysfunction (as seen in AD) could potentially be attributed to ASIC3. Future research concentrated on the role of ASIC 3 in microglial cells could provide evidence for therapeutic targeting against this cellular channel to diminish pain associated with certain neurological conditions.

\section{ASICs in Oligodendrocytes}

Using imaging and immunofluorescence techniques, it has been determined that ASIC1a, ASIC2a, and ASIC4 mRNAs are expressed in oligodendrocyte lineage cells (OLC) [118]. When oligodendrocytes are treated with PcTx1, a selective inhibitor for ASIC1a, electrical currents are almost completely blocked as well, indicating a high expression of ASIC1a in OLC [118]. This proves that ASIC1a is found extensively in oligodendrocytes, and thus plays a substantial role in white matter function.

Oligodendrocytes serve primarily to form myelin sheaths which enhance electrical conduction of synaptic transmissions in the brain [57]. NG2-glia, also known as oligodendrocyte precursor cells (OPC), function to give rise to mature oligodendrocytes that then allow for myelin sheath formation [119]. OPC also forms tight homeostatic networks that maintain cell numbers. Thus, they are very effective for repopulation [52]. ASIC1a is the predominant ASIC component found in OPC and mature oligodendrocytes [119]. ASIC1a plays a significant role in the signaling pathways of OLC [118], which ultimately leads to myelin production and rapid saltatory conduction.

Oligodendrocyte dysfunction is implicated in several disease processes, most notably multiple sclerosis (MS) [120]. MS is characterized as an autoimmune disease resulting in progressive demyelination of CNS axons, ultimately leading to severe neurological pathology [121]. One proposed mechanism relates to the propensity for ASIC1 oligodendrocytes to be highly susceptible to calcium overload [122,123]. Recent studies show that ASIC2 also contributes to MS [124]. Using the EAE model in ASIC1 and ASIC2 KO mice, a significant reduction in clinical scoring was found not only in ASIC1 KO mice, but also in ASIC2 KO mice at days 20-23 after immunization [124]. The underlying mechanism of ASIC1a involved in MS might be due to activation of ASIC1a resulting in overload of intracellular $\mathrm{Ca}^{2+}$ in the EAE model [123]. Modulation of ASIC1a surface expression by deletion of ASIC2 might also contribute to MS [108], but this should be investigated in future studies.

OPC plays an important role in chronic conditions such as obesity and cancer $[125,126]$. OPC makes contact with leptin receptors on dendritic processes, which helps to regulate the electrical response of leptin in the body [125]. Since ASIC1a is prominently found in OPC [119], it can be postulated that ASIC1a holds a significant role in leptin signaling. When OPC is destroyed or ASIC1 in OPC are not functioning properly, obesity risk is hypothesized to increase [125]. Furthermore, OPC proteins are highly expressed in gliomas and are shown to promote tumor origination and progression [126]. Again, since ASIC1a is predominantly found in OPC, it can be predicted that this channel plays a specific role in OPC function. A direct focus on this in future studies would be necessary to confirm.

\section{Perspective}

ASICs are expressed in glial cells. In this review, we discussed the integral roles that ASICs play in glial cell physiology and pathology, and how each unique ASIC component contributes to the specified function of each glial cell type. While lots of information exists on the topic, there are still many knowledge gaps within the literature. This section aims to summarize the major findings of the review and provide guidance for future research in the field.

\subsection{Astrocytic ASICs}

Astrocytes play major roles in support and regulation of physiological and pathological states $[42,53,58]$. While multiple ASICs exist within astrocytes, ASIC1 plays a predominant role in both healthy and disease-state conditions [78]. Physiologically, ASIC1a plays a unique role by contributing to motor coordination, homeostasis, and LTP in learning and memory through depolarization and $\mathrm{Ca}^{2+}$ influx $[84,85,106]$. Pathologically, ASIC1a 
demonstrates a specific contribution to the progression of various disease-state conditions. Thus, when ASIC1a is inhibited, protective effects in neurodegenerative diseases, ischemic conditions, and brain tumor are observed [13,88-90,126].

Despite these general findings, no studies directly focus on this relationship between ASICs in astrocytes and specific physiological or pathological outcomes. For example, there has been a lot of evidence that inhibition of ASIC1a or deletion of ASIC1a gene in neurons leads to protection during pathological conditions [26,27], but no research has specifically targeted astrocytic ASIC1a and explored its effects. Therefore, future research in the field should target the ASIC1a component of astrocytes using astrocyte-specific conditional $\mathrm{KO}$ mice to garner a more explicit understanding of its biological role. This could ultimately lead to the development of targeted astrocytic ASIC1a therapies for serious neurological diseases. For instance, stroke and ischemic brain injury contribute as significant mechanisms for mortality. Thus, further research opportunities could aim to understand the role in modulation of ASIC1a in astrocytes in order to emphasize potential protective roles in patients who are considered to be "high risk" for stroke and ischemic brain injury. In addition to ASIC1a involvement in neurological diseases, modulation of ASIC1a may reveal a promising therapeutic potential for treatment of gliomas. Since ASIC1a not only plays a significant role in the mechanism of glial tumors, but also in their serious neurological side effects, further research is required to determine how treatments focusing on ASIC1a can mitigate side effects, as well as delay progression of the disease.

\subsection{Microglial ASICs}

Microglia execute the primary role of phagocytosis in the brain [127]. This is important for regular debris clearing in healthy conditions and extensive debris clearing in disease conditions. Physiologically, ASIC1, ASIC2, and ASIC3 are found extensively in microglia [103]. ASIC2 acts primarily as a synergist for ASIC1, helping traffic ASIC1 to the plasma membrane allowing for its normal functioning [106]. Under physiological stimulation, ASIC1 and ASIC2 are upregulated to improve the efficiency of microglial function [103]. ASIC3, on the other hand, is primarily involved in pain sensation and regulation [117]. When microglia do not execute phagocytosis properly, such as when they are overwhelmed during $\mathrm{AD}$, there is prominent plaque build-up. This excess debris accentuates a cytokine storm which contributes to further inflammation and worsens the overall pathological condition [117].

There have been many studies that focus on the relationship between microglial malfunction and ensuing inflammation [103,117]. However, while ASIC1 and ASIC3 are targets during inflammatory states [128], no research directly focuses on the contribution of ASIC1 and/or ASIC3 specifically to the function of microglial cells under physiological or pathological states. It is still unknown how ASICs contribute to the primary role of phagocytosis in microglia, even though the literature shows that these channels are expressed on their membranes. For example, it is known that microglial cells are key players when the brain undergoes liquefactive necrosis, however there is no information in the literature on how microglial ASICs play a role in this condition. Furthermore, while we know that ASIC3 is also expressed in microglial cells and that ASIC3 has a primary function in pain modulation, no studies focus on microglial ASIC3 and how this regulates pain during inflammatory states such as AD. Thus, disruption of each functional ASIC subunit in glial cells is critical for further studies in this field. By focusing on these channel-specific components of microglial cells, targeted therapeutics can be developed which help to address certain aspects of inflammatory diseases $[129,130]$.

\subsection{Oligodendrocytic ASICs}

Oligodendrocytes are myelin-producing cells which insulate axons to allow for enhanced neuronal transmission [110]. ASIC1a is the primary component found in both OPC and mature oligodendrocytes [119]. It has been determined that ASIC1a is utilized in the division and differentiation of OPC through intracellular $\mathrm{Ca}^{2+}$ signaling, making it an important 
component in the myelin formation process [119]. From a pathological standpoint, ASIC1 in oligodendrocytes has been shown to play a major role in neurodegenerative diseases, specifically in MS [123]. Under the acidic conditions of MS, ASIC1a is highly activated in oligodendrocytes. This leads to oligodendrocyte injury and consequent demyelination. Contrarily, when ASIC1 is inhibited by amiloride, myelo-protective and neuroprotective effects are observed [123]. Additionally, ablation of OPC tends to promote obesity [125], whereas inhibition of OPC through antibodies prevents progression of brain cancer [126].

Oligodendrocytic ASIC1 might directly contribute to disease conditions, specifically MS [123]. MS is the primary neurodegenerative disease related to ASIC1 in oligodendrocytes. Future research could concentrate on oligodendrocytic ASIC1 contribution to other demyelinating diseases, such as acute disseminated encephalomyelitis. Moreover, few studies focus on the role of ASIC1 in OPC. ASIC1a in OPC reveals calcium permeability [119], however whether it has a role in leptin signaling needs to be determined; therefore, future studies would need to specifically focus on ASIC1 in OPC in order to confirm its relationship with obesity. In the same regard, OPC proteoglycans are highly expressed in gliomas and definitely contribute to tumor progression [126]. However, no studies focus on the role of ASIC1 in neoplasia. Further studies in the area of glioma therapeutics should target the role of ASIC1 in OPC to determine the consequent impact on glioma growth.

\section{Conclusions}

This review focuses on the theme of ASICs in glial cells from limited literature, summarizing their expression; detailing how ASICs in astrocytes, microglia, and oligodendrocytes contribute to physiological function and how pathological environments perpetuate ASIC dysregulation to result in disease presentations; and describing research gaps between ASICs and glial cells (Table 1). This is important as prior reviews have not gathered ASIC information for each of the glial cell types and discussed how the ASIC-glia relationship relates to specific physiology and pathology.

Table 1. ASICs in glial cells: Expression, Function and Research Gap.

\begin{tabular}{|c|c|c|c|}
\hline $\begin{array}{l}\text { Glial Cell } \\
\text { Subtype }\end{array}$ & $\begin{array}{l}\text { ASIC Subtype } \\
\text { Expression }\end{array}$ & $\begin{array}{l}\text { Physiological Function of Major } \\
\text { ASICs }\end{array}$ & Pathological Focus of ASICs and Research Gap \\
\hline Astrocytes & 1, 2, 3 [77] & $\begin{array}{l}\text { ASIC1a-influx of } \mathrm{Na}^{+} \text {and } \mathrm{Ca}^{2+} \text { ions } \\
\text { when } \mathrm{pH} \text { levels drop below } 7.0 \text {; rapid } \\
\text { depolarization of cell membrane } \\
\text { [77,78]. } \\
\text { ASIC2 and ASIC3-slowly } \\
\text { depolarizing to generate sustained } \\
\text { currents [77]. }\end{array}$ & $\begin{array}{l}\text { ASIC1a activation implicated in neurodegeneration } \\
\text { [26,86,87], ischemia [13,92,93], and glioma [97,98]. } \\
\text { Research Gap: explore the role of ASIC1a in astrocytes } \\
\text { towards neurodegenerative diseases, ischemia, and cancer. } \\
\text { Research Gap: developing a more detailed understanding of } \\
\text { the role of ASIC2 and ASIC3 in astrocytes in pathological } \\
\text { processes. }\end{array}$ \\
\hline Microglia & 1a, 2a, 3 [103] & $\begin{array}{l}\text { ASIC1a-influx of } \mathrm{Na}^{+} \text {and } \mathrm{Ca}^{2+} \text { ions } \\
\text { when pH levels drop below } 7.0 \text {; rapid } \\
\text { depolarization of cell membrane } \\
\text { [14,103]. } \\
\text { ASIC2a-activated when pH levels } \\
\text { drop below } 5.5 \text {; increases ASIC1 } \\
\text { co-localization [107,108]. } \\
\text { ASIC3-activated when pH levels } \\
\text { drop below } 7.0 \text {; pain modulation } \\
{[15,21] \text {. }}\end{array}$ & $\begin{array}{l}\text { ASIC1a and ASIC2a overexpression in plaque accumulation } \\
\text { of Alzheimer's Disease (AD) }[86,103,116] \text {. } \\
\text { Research Gap: targeted research on microglial ASIC1a and } \\
\text { ASIC2a in AD. } \\
\text { ASIC3 overexpression in hyperalgesia [87]. } \\
\text { Research Gap: specific understanding of microglial ASIC3 in } \\
\text { pain modulation. }\end{array}$ \\
\hline Oligodendrocytes & 1a, 2a, $4[118,119]$ & $\begin{array}{l}\text { ASIC1a-influx of } \mathrm{Na}^{+} \text {and } \mathrm{Ca}^{2+} \text { ions } \\
\text { when pH levels drop below 7.0; Rapid } \\
\text { depolarization of cell membrane [119]. } \\
\text { ASIC2a-modulation of ASIC1a } \\
\text { surface expression [107,108]. } \\
\text { ASIC4-Research Gap }\end{array}$ & $\begin{array}{l}\text { ASIC1a activation implicated in multiple sclerosis (MS) [122]. } \\
\text { Research Gap: understanding the specific role of } \\
\text { oligodendrocyte ASIC1 in MS. } \\
\text { ASIC2 knockout associated with better clinical scoring in } \\
\text { EAE. } \\
\text { Research Gap: exploring oligodendrocyte ASIC2 in MS. } \\
\text { Research Gap: understanding oligodendrocyte ASIC4 in } \\
\text { disease. }\end{array}$ \\
\hline
\end{tabular}

These findings help organize information for future research to concentrate on channelspecific components in individual glial cells. The gaps outlined in this review provide 
guidance for areas of concentration in glial ASIC research to promote targeted therapeutic options for various disease conditions.

Author Contributions: Conceptualization, V.C., R.C. and X.-P.C.; writing-original draft preparation, V.C., R.C. and X.-P.C.; writing-review and editing, S.D., M.J.W. and P.M.-N.; supervision, X.-P.C.; funding acquisition, X.-P.C. All authors have read and agreed to the published version of the manuscript.

Funding: This research was funded by American Heart Association grant number 19AIREA34470007.

Institutional Review Board Statement: Not applicable.

Informed Consent Statement: Not applicable.

Data Availability Statement: Not applicable.

Acknowledgments: We would like to thank the University of Missouri-Kansas City School of Medicine student research program for their support of V.C. and R.C's professional studies. X.P.C. acknowledges the support from the American Heart Association (grant number: 19AIREA34470007). S.D. acknowledges the support from the National Institute of Health (R01NS069726).

Conflicts of Interest: The authors declare no conflict of interest.

\section{Abbreviations}

$\begin{array}{ll}\text { AD } & \text { Alzheimer's disease } \\ \text { ASICs } & \text { acid-sensing ion channels } \\ \text { CNS } & \text { central nervous system } \\ \text { DEG } & \text { degenerin } \\ \text { DTA } & \text { diphtheria toxin A } \\ \text { EAE } & \text { experimental autoimmune encephalitis } \\ \text { ENaC } & \text { epithelial sodium channel } \\ \text { GFAP } & \text { glial fibrillary acidic protein } \\ \text { GMQ } & \text { 2-guanidine-4-methylquinazoline } \\ \text { HV } & \text { voltage-gated proton channel } \\ \text { HSV-TK } & \text { herpes simplex virus-thymidine kinase } \\ \text { KO } & \text { Knock-out } \\ \text { LPS } & \text { lipopolysaccharides } \\ \text { LTD } & \text { long-term depression } \\ \text { LTP } & \text { Long-term potentiation } \\ \text { MCAO } & \text { middle cerebral artery occlusion } \\ \text { MS } & \text { multiple sclerosis } \\ \text { NO } & \text { nitric oxide } \\ \text { OLC } & \text { oligodendrocyte lineage cells } \\ \text { OPC } & \text { oliodendrocyte precursor cells } \\ \text { PcTx1 } & \text { psalmotoxin-1 } \\ \text { PD } & \text { Parkinson's disease } \\ \text { pH } & \text { half activation value of ASICs by pH } \\ \text { ROS } & \text { reactive oxidative species } \\ \text { WT } & \text { wild-type }\end{array}$

\section{References}

1. Waldmann, R.; Champigny, G.; Bassilana, F.; Heurteaux, C.; Lazdunski, M. A proton-gated cation channel involved in acid-sensing. Nature 1997, 386, 173-177. [CrossRef] [PubMed]

2. Krishtal, O. Receptor for protons: First observations on acid sensing ion channels. Neuropharmacology 2015, 94, 4-8. [CrossRef] [PubMed]

3. Kellenberger, S.; Schild, L. International Union of Basic and Clinical Pharmacology. XCI. Structure, function, and pharmacology of acid-sensing ion channels and the epithelial $\mathrm{Na}^{+}$channel. Pharmacol. Rev. 2015, 67, 1-35. [CrossRef] [PubMed]

4. Gründer, S.; Chen, X. Structure, function, and pharmacology of acid-sensing ion channels (ASICs): Focus on ASIC1a. Int. J. Physiol. Pathophysiol. Pharmacol. 2010, 2, 73-94.

5. Yoder, N.; Yoshioka, C.; Gouaux, E. Gating mechanisms of acid-sensing ion channels. Nature 2018, 555, 397-401. [CrossRef] 
6. Yoder, N.; Gouaux, E. The His-Gly motif of acid-sensing ion channels resides in a reentrant 'loop' implicated in gating and ion selectivity. Elife 2020, 9, e56527. [CrossRef]

7. Jasti, J.; Furukawa, H.; Gonzales, E.B.; Gouaux, E. Structure of an acid-sensing ion channel 1 at 1.9 A resolution and low pH Nature 2007, 449, 316-323. [CrossRef]

8. Baconguis, I.; Gouaux, E. Structural plasticity and dynamic selectivity of acid-sensing ion channel-spider toxin complexes. Nature 2012, 489, 400-405. [CrossRef]

9. Cristofori-Armstrong, B.; Rash, L.D. Acid-sensing ion channel (ASIC) structure and function: Insights from spider, snake and sea anemone venoms. Neuropharmacology 2017, 127, 173-184. [CrossRef]

10. Boscardin, E.; Alijevic, O.; Hummler, E.; Frateschi, S.; Kellenberger, S. The function and regulation of acid-sensing ion channels (ASICs) and the epithelial Na channel (ENaC): IUPHAR Review 19. Br. J. Pharmacol. 2016, 173, 2671-2701. [CrossRef]

11. Rook, M.L.; Musgaard, M.; MacLean, D.M. Coupling structure with function in acid-sensing ion channels: Challenges in pursuit of proton sensors. J. Physiol. 2021, 599, 417-430. [CrossRef]

12. Yermolaieva., O.; Leonard, A.S.; Schnizler, M.K.; Abboud, F.M.; Welsh, M.J. Extracellular acidosis increases neuronal cell calcium by activating acid-sensing ion channel 1a. Proc. Natl. Acad. Sci. USA 2004, 101, 6752-6757. [CrossRef]

13. Xiong, Z.G.; Zhu, X.M.; Chu, X.P.; Minami, M.; Hey, J.; Wei, W.L.; MacDonald, J.F.; Wemmie, J.A.; Price, M.P.; Welsh, M.J.; et al Neuroprotection in ischemia: Blocking calcium-permeable acid-sensing ion channels. Cell 2004, 118, 687-698. [CrossRef]

14. Gründer, S.; Pusch, M. Biophysical properties of acid-sensing ion channels (ASICs). Neuropharmacology 2015, 94, 9-18. [CrossRef]

15. Wemmie, J.A.; Taugher, R.J.; Kreple, C.J. Acid-sensing ion channels in pain and disease. Nat. Rev. Neurosci. 2013, 14, 461-471. [CrossRef]

16. Storozhuka, M.; Cherninskyia, A.; Maximyuka, O.; Isaeva, D.; Krishtala, O. Acid-sensing ion channels: Focus on physiological and some pathological roles in the brain. Curr. Neuropharmacol. 2021, 19, 1570-1589. [CrossRef]

17. Lin, L.H.; Jones, S.; Talman, W.T. Cellular localization of acid-sensing ion channel 1 in rat nucleus tractus solitarii. Cell. Mol. Neurobiol. 2018, 38, 219-232. [CrossRef]

18. Price, M.P.; Gong, H.; Parsons, M.G.; Kundert, J.R.; Reznikov, L.R.; Bernardinelli, L.; Chaloner, K.; Buchanan, G.F.; Wemmie, J.A.; Richerson, G.B.; et al. Localization and behaviors in null mice suggest that ASIC1 and ASIC2 modulate responses to aversive stimuli. Genes Brain Behav. 2014, 13, 179-194. [CrossRef]

19. Chang, C.T.; Fong, S.W.; Lee, C.H.; Lin, S.H.; Chen, C.C. Involvement of acid-sensing ion channel $1 \mathrm{~b}$ in the development of acid-induced chronic muscle pain. Front. Neurosci. 2019, 13, 1247. [CrossRef]

20. Wu, W.L.; Cheng, S.J.; Lin, S.H.; Chuang, Y.C.; Huang, E.Y.; Chen, C.C. The effect of ASIC3 knockout on corticostriatal circuit and mouse self-grooming behavior. Front. Cell. Neurosci. 2019, 13, 86. [CrossRef]

21. Dulai, J.S.; Smith, E.S.J.; Rahman, T. Acid-sensing ion channel 3: An analgesic target. Channels 2021, 15, 94-127. [CrossRef] [PubMed]

22. Du, J.; Reznikov, L.R.; Price, M.P.; Zha, X.M.; Lu, Y.; Moninger, T.O.; Wemmie, J.A.; Welsh, M.J. Protons are a neurotransmitter that regulates synaptic plasticity in the lateral amygdala. Proc. Natl. Acad. Sci. USA 2014, 111, 8961-8966. [CrossRef] [PubMed]

23. Yu, Y.; Chen, Z.; Li, W.G.; Cao, H.; Feng, E.G.; Yu, F.; Liu, H.; Jiang, H.; Xu, T.L. A nonproton ligand sensor in the acid-sensing ion channel. Neuron 2010, 68, 61-72. [CrossRef] [PubMed]

24. Gautschi, I.; van Bemmelen, M.X.; Schild, L. Proton and non-proton activation of ASIC channels. PLoS ONE 2017, 12, e0175293. [CrossRef] [PubMed]

25. Bohlen, C.J.; Chesler, A.T.; Sharif-Naeini, R.; Medzihradszky, K.F.; Zhou, S.; King, D.; Sánchez, E.E.; Burlingame, A.L.; Basbaum, A.I.; Julius, D. A heteromeric Texas coral snake toxin targets acid-sensing ion channels to produce pain. Nature 2011, 479, 410-414. [CrossRef]

26. Chu, X.P.; Grasing, K.A.; Wang, J.Q. Acid-sensing ion channels contribute to neurotoxicity. Transl. Stroke Res. 2014, 5, 69-78. [CrossRef] [PubMed]

27. Chu, X.P.; Xiong, Z.G. Physiological and pathological functions of acid-sensing ion channels in the central nervous system. Curr Drug Targets 2012, 13, 263-271. [CrossRef]

28. Baron, A.; Lingueglia, E. Pharmacology of acid-sensing ion channels-physiological and therapeutical perspectives. Neuropharmacology 2015, 94, 19-35. [CrossRef] [PubMed]

29. Vullo, S.; Kellenberger, S. A molecular view of the function and pharmacology of acid-sensing ion channels. Pharmacol. Res. 2020, 154, 104166. [CrossRef]

30. Dibas, A.; Dibas, J.; Al-Saad, H. Basics on the use of acid-sensing ion channels' inhibitors as therapeutics. Neural Regen. Res. 2019, 14, 395. [CrossRef]

31. Dubé, G.R.; Lehto, S.G.; Breese, N.M.; Baker, S.J.; Wang, X.; Matulenko, M.A.; Honoré, P.; Stewart, A.O.; Moreland, R.B.; Brioni, J.D. Electrophysiological and in vivo characterization of A-317567, a novel blocker of acid sensing ion channels. Pain 2005, 117, 88-96. [CrossRef] [PubMed]

32. Báez, A.; Salceda, E.; Fló, M.; Graña, M.; Fernández, C.; Vega, R.; Soto, E. $\alpha$-Dendrotoxin inhibits the ASIC current in dorsal root ganglion neurons from rat. Neurosci. Lett. 2015, 606, 42-47. [CrossRef] [PubMed]

33. Escoubas, P.; Bernard, C.; Lambeau, G.; Lazdunski, M.; Darbon, H. Recombinant production and solution structure of PcTx1, the specific peptide inhibitor of ASIC1a proton-gated cation channels. Protein Sci. 2003, 12, 1332-1343. [CrossRef] 
34. Cristofori-Armstrong, B.; Saez, N.J.; Chassagnon, I.R.; King, G.F.; Rash, L.D. The modulation of acid-sensing ion channel 1 by PcTx1 is pH-, subtype- and species-dependent: Importance of interactions at the channel subunit interface and potential for engineering selective analogues. Biochem. Pharmacol. 2019, 163, 381-390. [CrossRef]

35. Jensen, J.E.; Durek, T.; Alewood, P.F.; Adams, D.J.; King, G.F.; Rash, L.D. Chemical synthesis and folding of APETx2, a potent and selective inhibitor of acid sensing ion channel. Toxicon 2009, 54, 56-61. [CrossRef]

36. Andreev, Y.A.; Osmakov, D.I.; Koshelev, S.G.; Maleeva, E.E.; Logashina, Y.A.; Palikov, V.A.; Palikova, Y.A.; Dyachenko, I.A.; Kozlov, S.A. Analgesic activity of acid-sensing ion channel 3 (ASIC3) inhibitors: Sea anemones peptides Ugr9-1 and APETx2 versus low molecular weight compounds. Mar. Drugs. 2018, 16, 500. [CrossRef]

37. Diochot, S.; Baron, A.; Salinas, M.; Douguet, D.; Scarzello, S.; Dabert-Gay, A.-S.; Debayle, D.; Friend, V.; Alloui, A.; Lazdunski, M.; et al. Black mamba venom peptides target acid-sensing ion channels to abolish pain. Nature 2012, 490, 552-555. [CrossRef]

38. Sun, D.; Liu, S.; Li, S.; Zhang, M.; Yang, F.; Wen, M.; Shi, P.; Wang, T.; Pan, M.; Chang, S.; et al. Structural insights into human acid-sensing ion channel 1a inhibition by snake toxin mambalgin1. Elife. 2020, 9, e57096. [CrossRef]

39. Rash, L.D. Acid-sensing ion channel pharmacology, past, present, and future ... . Adv. Pharmacol. 2017, $79,35-66$.

40. Hirbec, H.; Déglon, N.; Foo, L.C.; Goshen, I.; Grutzendler, J.; Hangen, E.; Kreisel, T.; Linck, N.; Muffat, J.; Regio, S.; et al. Emerging technologies to study glial cells. Glia 2020, 68, 1692-1728. [CrossRef]

41. Cohen-Salmon, M.; Slaoui, L.; Mazaré, N.; Gilbert, A.; Oudart, M.; Alvear-Perez, R.; Elorza-Vidal, X.; Chever, O.; Boulay, A.C. Astrocytes in the regulation of cerebrovascular functions. Glia 2021, 69, 817-841. [CrossRef]

42. Verkhratsky, A.; Nedergaard, M. Physiology of astroglia. Physiol. Rev. 2018, 98, 239-389. [CrossRef]

43. Santello, M.; Toni, N.; Volterra, A. Astrocyte function from information processing to cognition and cognitive impairment. Nat. Neurosci. 2019, 22, 154-166. [CrossRef]

44. Umpierre, A.D.; Wu, L.J. How microglia sense and regulate neuronal activity. Glia 2021, 69, 1637-1653. [CrossRef]

45. Cserép, C.; Pósfai, B.; Dénes, Á. Shaping neuronal fate: Functional heterogeneity of direct microglia-neuron interactions. Neuron 2021, 109, 222-240. [CrossRef]

46. Wright-Jin, E.C.; Gutmann, D.H. Microglia as dynamic cellular mediators of brain function. Trends Mol. Med. 2019, 25, 967-979. [CrossRef]

47. Prinz, M.; Jung, S.; Priller, J. Microglia biology: One century of evolving concepts. Cell 2019, 179, 292-311. [CrossRef]

48. Kol, A.; Goshen, I. The memory orchestra: The role of astrocytes and oligodendrocytes in parallel to neurons. Curr. Opin. Neurobiol. 2021, 67, 131-137. [CrossRef]

49. Pease-Raissi, S.E.; Chan, J.R. Building a (w)rapport between neurons and oligodendroglia: Reciprocal interactions underlying adaptive myelination. Neuron 2021, 109, 1258-1273. [CrossRef]

50. Akay, L.A.; Effenberger, A.H.; Tsai, L.H. Cell of all trades: Oligodendrocyte precursor cells in synaptic, vascular, and immune function. Genes Dev. 2021, 35, 180-198. [CrossRef] [PubMed]

51. Sancho, L.; Contreras, M.; Allen, N.J. Glia as sculptors of synaptic plasticity. Neurosci. Res. 2021, 167, 17-29. [CrossRef]

52. Jäkel, S.; Dimou, L. Glial cells and their function in the adult brain: A journey through the history of their ablation. Front. Cell. Neurosci. 2017, 11, 24. [CrossRef] [PubMed]

53. Singh, A.; Abraham, W.C. Astrocytes and synaptic plasticity in health and disease. Exp. Brain Res. 2017, 235, 1645-1655. [CrossRef]

54. Wolf, S.A.; Boddeke, H.W.; Kettenmann, H. Microglia in physiology and disease. Annu. Rev. Physiol. 2017, 79, 619-643. [CrossRef]

55. Li, Q.; Barres, B.A. Microglia and macrophages in brain homeostasis and disease. Nat. Rev. Immunol. 2018, 18, 225-242. [CrossRef]

56. Osso, L.A.; Chan, J.R. Architecting the myelin landscape. Curr. Opin. Neurobiol. 2017, 47, 1-7. [CrossRef]

57. Kuhn, S.; Gritti, L.; Crooks, D.; Dombrowski, Y. Oligodendrocytes in development, myelin generation and beyond. Cells $2019,8,1424$. [CrossRef]

58. Chung, W.S.; Allen, N.J.; Eroglu, C. Astrocytes control synapse formation, function, and elimination. Cold Spring Harb. Perspect. Biol. 2015, 7, a020370. [CrossRef] [PubMed]

59. Cui, W.; Allen, N.D.; Skynner, M.; Gusterson, B.; Clark, A.J. Inducible ablation of astrocytes shows that these cells are required for neuronal survival in the adult brain. Glia 2001, 34, 272-282. [CrossRef]

60. Schreiner, B.; Romanelli, E.; Liberski, P.; Ingold-Heppner, B.; Sobottka-Brillout, B.; Hartwig, T.; Chandrasekar, V.; Johannssen, H.; Zeilhofer, H.U.; Aguzzi, A.; et al. Astrocyte depletion impairs redox homeostasis and triggers neuronal loss in the adult CNS. Cell Rep. 2015, 12, 1377-1384. [CrossRef]

61. Wilton, D.K.; Dissing-Olesen, L.; Stevens, B. Neuron-glia signaling in synapse elimination. Annu. Rev. Neurosci. 2019, 42, 107-127. [CrossRef]

62. Vasile, F.; Dossi, E.; Rouach, N. Human astrocytes: Structure and functions in the healthy brain. Brain Struct. Funct. 2017, 222, 2017-2029. [CrossRef] [PubMed]

63. Elmore, M.R.P.; Lee, R.J.; West, B.L.; Green, K.N. Characterizing newly repopulated microglia in the adult mouse: Impacts on animal behavior, cell morphology, and neuroinflammation. PLoS ONE 2015, 10, e0122912. [CrossRef]

64. Bruttger, J.; Karram, K.; Wörtge, S.; Regen, T.; Marini, F.; Hoppmann, N.; Klein, M.; Blank, T.; Yona, S.; Wolf, Y.; et al. Genetic cell ablation reveals clusters of local self-renewing microglia in the mammalian central nervous system. Immunity 2015, 43, 92-106. [CrossRef]

65. Torres, L.; Danver, J.; Ji, K.; Miyauchi, J.T.; Chen, D.; Anderson, M.E.; West, B.L.; Robinson, J.K.; Tsirka, S.E. Dynamic microglial modulation of spatial learning and social behavior. Brain Behav. Immun. 2016, 55, 6-16. [CrossRef] [PubMed] 
66. Parkhurst, C.N.; Yang, G.; Ninan, I.; Savas, J.N.; Yates, J.R., 3rd; Lafaille, J.J.; Hempstead, B.L.; Littman, D.R.; Gan, W.-B. Microglia promote learning-dependent synapse formation through brain-derived neurotrophic factor. Cell 2013, 155, 1596-1609. [CrossRef] [PubMed]

67. Arcuri, C.; Mecca, C.; Bianchi, R.; Giambanco, I.; Donato, R. The pathophysiological role of microglia in dynamic surveillance, phagocytosis and structural remodeling of the developing CNS. Front. Mol. Neurosci. 2017, 10, 191. [CrossRef] [PubMed]

68. Traka, M.; Podojil, J.R.; McCarthy, D.P.; Miller, S.D.; Popko, B. Oligodendrocyte death results in immune-mediated CNS demyelination. Nat. Neurosci. 2016, 19, 65-74. [CrossRef] [PubMed]

69. Ghosh, A.; Manrique-Hoyos, N.; Voigt, A.; Schulz, J.B.; Kreutzfeldt, M.; Merkler, D.; Simons, M. Targeted ablation of oligodendrocytes triggers axonal damage. PLoS ONE 2011, 6, e22735. [CrossRef]

70. Gritsch, S.; Lu, J.; Thilemann, S.; Wörtge, S.; Möbius, W.; Bruttger, J.; Karram, K.; Ruhwedel, T.; Blanfeld, M.; Vardeh, D.; et al. Oligodendrocyte ablation triggers central pain independently of innate or adaptive immune responses in mice. Nat. Commun. 2014, 5, 5472. [CrossRef] [PubMed]

71. Oluich, L.J.; Stratton, J.A.S.; Xing, Y.L.; Ng, S.W.; Cate, H.S.; Sah, P.; Windels, F.; Kilpatrick, T.J.; Merson, T.D. Targeted ablation of oligodendrocytes induces axonal pathology independent of overt demyelination. J. Neurosci. 2012, 32, 8317-8330. [CrossRef]

72. Faulkner, J.R. Reactive astrocytes protect tissue and preserve function after spinal cord injury. J. Neurosci. 2004, $24,2143-2155$. [CrossRef] [PubMed]

73. Voskuhl, R.R.; Peterson, R.S.; Song, B.; Ao, Y.; Morales, L.B.J.; Tiwari-Woodruff, S.; Sofroniew, M.V. Reactive astrocytes form scar-like perivascular barriers to leukocytes during adaptive immune inflammation of the CNS. J. Neurosci. 2009, 29, 11511-11522 [CrossRef] [PubMed]

74. Burda, J.E.; Bernstein, A.M.; Sofroniew, M.V. Astrocyte roles in traumatic brain injury. Exp. Neurol. 2016, 275, 305-315. [CrossRef]

75. Heppner, F.L.; Greter, M.; Marino, D.; Falsig, J.; Raivich, G.; Hövelmeyer, N.; Waisman, A.; Rülicke, T.; Prinz, M.; Priller, J.; et al. Experimental autoimmune encephalomyelitis repressed by microglial paralysis. Nat. Med. 2005, 11, 146-152. [CrossRef] [PubMed]

76. Lalancette-Hébert, M.; Gowing, G.; Simard, A.; Weng, Y.C.; Kriz, J. Selective ablation of proliferating microglial cells exacerbates ischemic injury in the brain. J. Neurosci. 2007, 27, 2596-2605. [CrossRef] [PubMed]

77. Huang, C.; Hu, Z.L.; Wu, W.N.; Yu, D.F.; Xiong, Q.J.; Song, J.R.; Shu, Q.; Fu, H.; Wang, F.; Chen, J.-G. Existence and distinction of acid-evoked currents in rat astrocytes. Glia 2010, 58, 1415-1424. [CrossRef]

78. Yang, F.; Sun, X.; Ding, Y.; Ma, H.; Yang, T.O.; Ma, Y.; Wei, D.; Li, W.; Xu, T.; Jiang, W. Astrocytic acid-sensing ion channel 1a contributes to the development of chronic epileptogenesis. Sci. Rep. 2016, 6, 31581. [CrossRef] [PubMed]

79. Kapoor, N.; Lee, W.; Clark, E.; Bartoszewski, R.; McNicholas, C.M.; Latham, C.B.; Bebok, Z.; Parpura, V.; Fuller, C.M.; Palmer, C.A.; et al. Interaction of ASIC1 and ENaC subunits in human glioma cells and rat astrocytes. Am. J. Physiol. Cell Physiol. 2011, 300, C1246-C1259. [CrossRef]

80. Rose, C.R.; Verkhratsky, A. Principles of sodium homeostasis and sodium signalling in astroglia. Glia 2016, 64, 1611-1627. [CrossRef]

81. Tauffenberger, A.; Magistretti, P.J. Reactive oxygen species: Beyond their reactive behavior. Neurochem. Res. 2021, 46, 77-87. [CrossRef]

82. MacVicar, B.A.; Newman, E.A. Astrocyte regulation of blood flow in the brain. Cold Spring Harb. Perspect. Biol. 2015, 7, a020388. [CrossRef]

83. Wemmie, J.A.; Chen, J.; Askwith, C.C.; Hruska-Hageman, A.M.; Price, M.P.; Nolan, B.C.; Yoder, P.G.; Lamani, E.; Hoshi, T.; Freeman, J.H., Jr.; et al. The acid-activated ion channel ASIC contributes to synaptic plasticity, learning, and memory. Neuron 2002, 34, 463-477. [CrossRef]

84. Liu, M.G.; Li, H.S.; Li, W.G.; Wu, Y.J.; Deng, S.N.; Huang, C.; Maximyuk, O.; Sukach, V.; Krishtal, O.; Zhu, M.X.; et al. Acid-sensing ion channel 1a contributes to hippocampal LTP inducibility through multiple mechanisms. Sci. Rep. 2016, 6, 23350. [CrossRef]

85. Uchitel, O.D.; González Inchauspe, C.; Weissmann, C. Synaptic signals mediated by protons and acid-sensing ion channels. Synapse 2019, 73, e22120. [CrossRef]

86. Gonzales, E.B.; Sumien, N. Acidity and acid-sensing ion channels in the normal and Alzheimer's disease brain. J. Alzheimers. Dis. 2017, 57, 1137-1144. [CrossRef]

87. Ortega-Ramírez, A.; Vega, R.; Soto, E. Acid-sensing ion channels as potential therapeutic targets in neurodegeneration and neuroinflammation. Mediat. Inflamm. 2017, 2017, 3728096. [CrossRef]

88. Arun, T.; Tomassini, V.; Sbardella, E.; de Ruiter, M.B.; Matthews, L.; Leite, M.I.; Gelineau-Morel, R.; Cavey, A.; Vergo, S.; Craner, M.; et al. Targeting ASIC1 in primary progressive multiple sclerosis: Evidence of neuroprotection with amiloride. Brain 2013, 136, 106-115. [CrossRef]

89. Arias, R.L.; Sung, M.L.A.; Vasylyev, D.; Zhang, M.Y.; Albinson, K.; Kubek, K.; Kagan, N.; Beyer, C.; Lin, Q.; Dwyer, J.M.; et al. Amiloride is neuroprotective in an MPTP model of Parkinson's disease. Neurobiol. Dis. 2008, 31, 334-341. [CrossRef]

90. Vig, P.J.S.; Hearst, S.M.; Shao, Q.; Lopez, M.E. Knockdown of acid-sensing ion channel 1a (ASIC1a) suppresses disease phenotype in SCA1 mouse model. Cerebellum 2014, 13, 479-490. [CrossRef]

91. Wong, H.K.; Bauer, P.O.; Kurosawa, M.; Goswami, A.; Washizu, C.; Machida, Y.; Tosaki, A.; Yamada, M.; Knöpfel, T.; Nakamura, T.; et al. Blocking acid-sensing ion channel 1 alleviates Huntington's disease pathology via an ubiquitin-proteasome systemdependent mechanism. Hum. Mol. Genet. 2008, 17, 3223-3235. [CrossRef] 
92. Wang, J.J.; Liu, F.; Yang, F.; Wang, Y.Z.; Qi, X.; Li, Y.; Hu, Q.; Zhu, M.X.; Xu, T.L. Disruption of auto-inhibition underlies conformational signaling of ASIC1a to induce neuronal necroptosis. Nat. Commun. 2020, 11, 475. [CrossRef]

93. Wang, Y.Z.; Wang, J.J.; Huang, Y.; Liu, F.; Zeng, W.Z.; Li, Y.; Xiong, Z.G.; Zhu, M.X.; Xu, T.L. Tissue acidosis induces neuronal necroptosis via ASIC1a channel independent of its ionic conduction. Elife 2015, 4, e05682. [CrossRef]

94. William, M.; Turnadzic, S.; Chu, X.P. Commentary: Therapeutic potential of targeting the auto-inhibition of ASIC1a for neuroprotection against ischemic brain injury. Front. Pharmacol. 2020, 11, 604892. [CrossRef]

95. Poirot, O.; Vukicevic, M.; Boesch, A.; Kellenberger, S. Selective regulation of acid-sensing ion channel 1 by serine proteases. J. Biol. Chem. 2004, 279, 38448-38457. [CrossRef]

96. Peterson, A.; Jiang, Q.; Chu, X.P. Commentary: Potential therapeutic consequences of an acid-sensing ion channel 1a-blocking antibody. Front. Pharmacol. 2019, 10, 954. [CrossRef]

97. Bubien, J.K.; Ji, H.L.; Gillespie, G.Y.; Fuller, C.M.; Markert, J.M.; Mapstone, T.B.; Benos, D.J. Cation selectivity and inhibition of malignant glioma $\mathrm{Na}^{+}$channels by psalmotoxin 1. Am. J. Physiol. Cell Physiol. 2004, 287, C1282-C1291. [CrossRef]

98. Weng, X.C.; Zheng, J.Q.; Li, J.; Xiao, W.B. Underlying mechanism of ASIC1a involved in acidosis-induced cytotoxicity in rat C6 glioma cells. Acta Pharmacol. Sin. 2007, 28, 1731-1736. [CrossRef]

99. Berdiev, B.K.; Xia, J.; McLean, L.A.; Markert, J.M.; Yancey Gillespie, G.; Mapstone, T.B.; Naren, A.P.; Jovov, B.; Bubien, J.K.; Ji, H.L.; et al. Acid-sensing ion channels in malignant gliomas. J. Biol. Chem. 2003, 278, 15023-15034. [CrossRef]

100. Sheng, Y.; Wu, B.; Leng, T.; Zhu, L.; Xiong, Z. Acid-sensing ion channel 1 (ASIC1) mediates weak acid-induced migration of human malignant glioma cells. Am. J. Cancer Res. 2021, 11, 997-1008.

101. Vila-Carriles, W.H.; Zhou, Z.H.; Bubien, J.K.; Fuller, C.M.; Benos, D.J. Participation of the chaperone Hsc70 in the trafficking and functional expression of ASIC2 in glioma cells. J. Biol. Chem. 2007, 282, 34381-34391. [CrossRef]

102. Rocha, P.R.F.; Medeiros, M.C.R.; Kintzel, U.; Vogt, J.; Araújo, I.M.; Mestre, A.L.G.; Mailänder, V.; Schlett, P.; Dröge, M.; Schneider, L.; et al. Extracellular electrical recording of pH-triggered bursts in C6 glioma cell populations. Sci. Adv. 2016, 2, e1600516. [CrossRef]

103. Yu, X.W.; Hu, Z.L.; Ni, M.; Fang, P.; Zhang, P.W.; Shu, Q.; Fan, H.; Zhou, H.Y.; Ni, L.; Zhu, L.Q.; et al. Acid-sensing ion channels promote the inflammation and migration of cultured rat microglia. Glia 2015, 63, 483-496. [CrossRef]

104. Wu, L.J. Microglial voltage-gated proton channel Hv1 in ischemic stroke. Transl. Stroke Res. 2014, 5, 99-108. [CrossRef]

105. Zeng, W.Z.; Liu, D.S.; Liu, L.; She, L.; Wu, L.J.; Xu, T.L. Activation of acid-sensing ion channels by localized proton transient reveals their role in proton signaling. Sci. Rep. 2015, 5, 14125. [CrossRef]

106. Zha, X.M. Acid-sensing ion channels: Trafficking and synaptic function. Mol. Brain 2013, 6, 1. [CrossRef]

107. Zha, X.M.; Costa, V.; Harding, A.M.S.; Reznikov, L.; Benson, C.J.; Welsh, M.J. ASIC2 subunits target acid-sensing ion channels to the synapse via an association with PSD-95. J. Neurosci. 2009, 29, 8438-8446. [CrossRef]

108. Jiang, N.; Wu, J.; Leng, T.; Yang, T.; Zhou, Y.; Jiang, Q.; Wang, B.; Hu, Y.; Ji, Y.H.; Simon, R.P.; et al. Region specific contribution of ASIC2 to acidosis-and ischemia-induced neuronal injury. J. Cereb. Blood Flow Metab. 2017, 37, 528-540. [CrossRef]

109. Carattino, M.D.; Montalbetti, N. Acid-sensing ion channels in sensory signaling. Am. J. Physiol. Ren. Physiol. 2020, 318, F531-F543. [CrossRef]

110. Deval, E.; Lingueglia, E. Acid-sensing ion channels and nociception in the peripheral and central nervous systems. Neuropharmacology 2015, 94, 49-57. [CrossRef]

111. Abdelhamid, R.E.; Sluka, K.A. ASICs mediate pain and inflammation in musculoskeletal diseases. Physiology 2015, 30, 449-459. [CrossRef]

112. Vullo, S.; Bonifacio, G.; Roy, S.; Johner, N.; Bernèche, S.; Kellenberger, S. Conformational dynamics and role of the acidic pocket in ASIC pH-dependent gating. Proc. Natl. Acad. Sci. USA 2017, 114, 3768-3773. [CrossRef] [PubMed]

113. Zuo, Z.; Smith, R.N.; Chen, Z.; Agharkar, A.S.; Snell, H.D.; Huang, R.; Liu, J.; Gonzales, E.B. Identification of a unique Ca ${ }^{2+}$-binding site in rat acid-sensing ion channel 3. Nat. Commun. 2018, 9, 2082. [CrossRef] [PubMed]

114. Gregory, N.S.; Brito, R.G.; Fusaro, M.C.G.O.; Sluka, K.A. ASIC3 is required for development of fatigue-induced hyperalgesia. Mol. Neurobiol. 2016, 53, 1020-1030. [CrossRef] [PubMed]

115. Njie, E.G.; Boelen, E.; Stassen, F.R.; Steinbusch, H.W.M.; Borchelt, D.R.; Streit, W.J. Ex vivo cultures of microglia from young and aged rodent brain reveal age-related changes in microglial function. Neurobiol. Aging 2012, 33, 195.e1-195. e12. [CrossRef]

116. Thakker, D.R.; Weatherspoon, M.R.; Harrison, J.; Keene, T.E.; Lane, D.S.; Kaemmerer, W.F.; Stewart, G.R.; Shafer, L.L. Intracerebroventricular amyloid-beta antibodies reduce cerebral amyloid angiopathy and associated micro-hemorrhages in aged Tg2576 mice. Proc. Natl. Acad. Sci. USA 2009, 106, 4501-4506. [CrossRef]

117. Valles, S.L.; Iradi, A.; Aldasoro, M.; Vila, J.M.; Aldasoro, C.; de la Torre, J.; Campos-Campos, J.; Jorda, A. Function of glia in aging and the brain diseases. Int. J. Med. Sci. 2019, 16, 1473-1479. [CrossRef]

118. Feldman, D.H.; Horiuchi, M.; Keachie, K.; Mccauley, E.; Bannerman, P.; Itoh, A.; Itoh, T.; Pleasure, D. Characterization of acid-sensing ion channel expression in oligodendrocyte-lineage cells. Glia 2008, 56, 1238-1249. [CrossRef]

119. Lin, Y.C.; Liu, Y.C.; Huang, Y.Y.; Lien, C.C. High-density expression of $\mathrm{Ca}^{2+}$-permeable ASIC1a channels in NG2 glia of rat hippocampus. PLoS ONE 2010, 5, e12665. [CrossRef]

120. Lubetzki, C.; Zalc, B.; Williams, A.; Stadelmann, C.; Stankoff, B. Remyelination in multiple sclerosis: From basic science to clinical translation. Lancet Neurol. 2020, 19, 678-688. [CrossRef] 
121. Absinta, M.; Lassmann, H.; Trapp, B.D. Mechanisms underlying progression in multiple sclerosis. Curr. Opin. Neurol. 2020, 33, 277-285. [CrossRef]

122. Liu, S.; Cheng, X.Y.; Wang, F.; Liu, C.F. Acid-sensing ion channels: Potential therapeutic targets for neurologic diseases. Transl. Neurodegener. 2015, 4, 10. [CrossRef]

123. Friese, M.A.; Craner, M.J.; Etzensperger, R.; Vergo, S.; Wemmie, J.A.; Welsh, M.J.; Vincent, A.; Fugger, L. Acid-sensing ion channel-1 contributes to axonal degeneration in autoimmune inflammation of the central nervous system. Nat. Med. 2007, 13, 1483-1489. [CrossRef]

124. Fazia, T.; Pastorino, R.; Notartomaso, S.; Busceti, C.; Imbriglio, T.; Cannella, M.; Gentilini, D.; Morani, G.; Ticca, A.; Bitti, P.; et al. Acid sensing ion channel 2: A new potential player in the pathophysiology of multiple sclerosis. Eur. J. Neurosci. 2019, 49, 1233-1243. [CrossRef]

125. Djogo, T.; Robins, S.C.; Schneider, S.; Kryzskaya, D.; Liu, X.; Mingay, A.; Gillon, C.J.; Kim, J.H.; Storch, K.F.; Boehm, U.; et al. Adult NG2-glia are required for median eminence-mediated leptin sensing and body weight control. Cell Metab. 2016, 23, 797-810. [CrossRef]

126. Yadavilli, S.; Hwang, E.I.; Packer, R.J.; Nazarian, J. The role of NG2 proteoglycan in glioma. Transl. Oncol. 2016, 9, 57-63. [CrossRef] [PubMed]

127. Galloway, D.A.; Phillips, A.E.M.; Owen, D.R.J.; Moore, C.S. Phagocytosis in the brain: Homeostasis and disease. Front. Immunol. 2019, 10, 790. [CrossRef]

128. Munro, G.; Christensen, J.K.; Erichsen, H.K.; Dyhring, T.; Demnitz, J.; Dam, E.; Ahring, P.K. NS383 selectively inhibits acid-sensing ion channels containing $1 \mathrm{a}$ and 3 subunits to reverse inflammatory and neuropathic hyperalgesia in rats. CNS Neurosci. Ther. 2016, 22, 135-145. [CrossRef] [PubMed]

129. Woods, D.; Jiang, Q.; Chu, X.P. Monoclonal antibody as an emerging therapy for acute ischemic stroke. Int. J. Physiol. Pathophysiol. Pharmacol. 2020, 12, 95-106.

130. Foster, V.S.; Rash, L.D.; King, G.F.; Rank, M.M. Acid-sensing ion channels: Expression and function in resident and infiltrating immune cells in the central nervous system. Front. Cell. Neurosci. 2021, 15, 738043. [CrossRef] [PubMed] 